Emplacement of the Nain anorthosite: diapiric vs. conduit ascent

K.R. Royse and R.G. Park

K.R. Royse: [Corresponding Author] Department of Earth Sciences, Keele University, Keele, Staffordshire, ST5 5BG, UK CURRENTLY AT: The British Geological Survey, Kingsley Dunham Centre, Keyworth, Nottingham, United Kingdom, NG12 5GG. TEL +44 (0115) 9363456 email: krro@wpo.nerc.ac.uk

R.G.Park: Department of Earth Sciences, Keele University, Keele, Staffordshire, ST5 5BG, UK. email: graham.park@easynet.co.uk 


\title{
Emplacement of the Nain anorthosite: diapiric vs. conduit ascent
}

\author{
K.R. Royse and R.G.Park
}

\begin{abstract}
Estimation of settling velocities of large orthopyroxene megacrysts, found within the anorthosite intrusions, are calculated and compared to ascent rates achieved by diapirism and by conduit propagation. Calculations suggest that diapirism is far too slow to be an appropriate ascent mechanism for anorthositic crystal mush and favour conduit emplacement. The intrusions of the Nain Plutonic Suite (NPS) are located along the Abloviak shear zone (which marks the boundary between the Nain and Churchill provinces) and within the zone of juxtaposition of the Saglek and Hopedale blocks of the Nain province. These crustal weaknesses have probably controlled the emplacement and distribution of the intrusions. Contact relations between intrusions of anorthosite and their gneissic host rock provide evidence for two emplacement styles within the NPS, the first typified by strongly deformed and recrystallised rocks, the second by an outer border zone of mafic rocks. It is proposed that these differences in intrusive style are due to differences in ductility contrast between the magma and its surrounding host rocks, such that those intrusions emplaced into the thermally softened shear zone have deformed margins, whereas those intruded into the cooler Archaean crust have undeformed margins.
\end{abstract}




\section{Introduction}

The Nain Plutonic Suite (NPS) is a composite body consisting of numerous intrusions of four major types: norite-anorthosite, troctolite, ferrodiorite, and quartz-monzonite (Williams et al. 1985; Ryan 1990a) emplaced between 1.35 and 1.29 Ga (Ryan and Emslie 1994). The intrusions straddle the boundary between the Nain province, an Archaean craton, and the Churchill province, a complex terrane of largely granulitefacies gneisses that includes reworked Archaean crust, deformed Paleoproterozoic charnockitic intrusions, and a major belt of Paleoproterozoic paragneiss (Fig. 1). This boundary is tectonic, and demarcates a continental suture zone. The deformation and metamorphic imprint of the suture zone defines the Torngat orogen (Fig.1; e.g., Mengel and Rivers 1989). The Torngat orogen is the result of oblique collision between the Nain and the Rae (Churchill) provinces at ca. 1845-1822 Ma (VanKranendonk and Wardle 1997), which resulted in the formation of the Abloviak shear zone. Post-collisional isostastic uplift in the southern Rae province resulted in reactivation of the orogen at ca. 1798-1770 Ma (Van Kranendonk and Wardle 1997); this continued episodically until $1710 \mathrm{Ma}($ Scott 1998).

In stark contrast to the anorthosites of the Grenville province to the south, the NPS rocks are largely undeformed, retaining their original primary igneous mineralogy, structures, and textures (Emslie et al. 1972; Taylor 1979; Emslie and Hunt 1990; and the Nain Anorthosite Project NAP 1971-1981). Deformation features observed in some of the 
intrusions, particularly in some of the marginal zones, have been attributed to the emplacement of a crystal-laden mush (Wiebe 1990).

The mode of emplacement of massif-type anorthosite plutons has been a topic of study for many decades (Simmons 1964; Berg 1977; Morse 1981). Some earlier workers assumed that anorthosite intrusions were linked to metamorphic processes in high-grade rocks (upper amphibolite to granulite facies) where they are commonly found (Martignole and Schrijver 1970). However, the argument for a direct genetic link between anorthosite intrusions and high-grade rocks is no longer supported. Valley and O’Neil (1982) measured the variation in oxygen isotope composition between the margins of the Adirondack anorthosite and wollastonite-bearing skarns. They found that these margins had spectacular gradients that could only be attributed to the exchange of oxygen isotopes with circulating hot meteoric water, implying an emplacement depth of not greater than $10 \mathrm{~km}$. Thermo-barometry carried out on the Laramie anorthosite (Wyoming) places its emplacement at 10-15 km depth, from estimates of crystallisation conditions of associated monzosyenites (Grant and Frost 1990). Work undertaken on the contact aureoles surrounding the NPS similarly indicates mid-crustal to upper crustal depths ( 6 to $14 \mathrm{~km}$ and $\sim 645-915^{\circ} \mathrm{C}$ ) as the sites of pluton crystallisation (Berg 1977; Speer 1982). Berg (1977) suggested that ambient temperature at the time of emplacement was probably no greater than $250-300^{\circ} \mathrm{C}$.

A possible mechanism for ascent mechanism is diapirism. In this model, hot magma ascends by density contrast into the crust. In order to rise, the diapir must soften its wall 
rocks, expending thermal energy in the process. In granitoid plutons, evidence for this mechanism of ascent comes from the field observations that plutons are roughly circular, and that they appear to have marginal deformation reminiscent of that expected in diapirism (Schmeling et al. 1988; Ramsay 1989; Cruden 1990). A note of caution to this theory was first sounded by Leake (1978) to the effect that emplacement geometry is not a reliable indication of ascent mechanism. The role of dykes in transporting magma has gained in popularity in recent years as the ascent mechanism responsible for the production of large batholiths (Clemens and Mawer 1992; Petford et al. 1993). The significance of faults and shear zones in controlling not only magma emplacement but also magma ascent has been recognised by many authors (Pitcher 1979; Castro 1987; Brun et al. 1990; Schmidt et al. 1990; D’Lemos et al. 1992; Petford and Atherton 1992).

Detailed mapping of the margins of the NPS by Ryan (1992) found that foliated margins to the anorthosite plutons were far more widespread than previously reported (Morse 1971-1983; Wiebe 1990), and he believed that these margins were genetically related to the emplacement of the NPS. The results of this work led to the re-examination of the NPS margins by the present authors. This paper, therefore, examines the marginal relationships between the anorthosite plutons and their host rocks, and discusses the constraints placed on pluton growth by the physical properties of the magma. A model for the emplacement of the Nain anorthosites is proposed which satisfies both field observations and physical constraints. 


\section{Regional Geology}

Gneisses. During fieldwork carried out as part of the first authors, Ph.D. thesis, the Archaean rocks, in the achipelago east of Nain, Labrador (Fig. 2), were examined in detail. The Archaean rocks lie on the boundary between the Saglek and Hopedale blocks (Fig.1), forming a narrow belt between the anorthosite plutons. They consist of amphibolite- to granulite-facies, migmatitic, tonalitic to trondhjemitic gneisses, basic gneisses, metasedimentary gneisses, and schlieric granitoid plutons (Royse 1997; Ryan 1991, 1993).

The gneissic foliation was found to strike north-south and dip at $50-90^{\circ}$ to the east (Fig. 2), although minor variation due to earlier deformation events complicates this pattern locally, particularly in the Dog Island area (Fig. 2). The migmatised gneisses contain a transposed foliation S0-S1 that was later regionally folded by northeast-trending folds (F2). The schlieric-granitoid gneisses, which have intruded in a lit-par-lit fashion into the migmatised gneisses, are also affected by this D2 event; hornblende and biotite define a NE- trending mineral lineation, which is parallel to the F2 fold axis. The schliericgranitoid gneisses do not display the same complex deformational history or the pervasive migmatisation seen in the migmatised gneisses. In places, relics of potassium feldspar phenocrysts, in schlieric-granitoid gneisses, lead to a porphyroclastic (augen) texture in outcrop.

It was found that this foliation trend appeared to deflect around the margins of certain anorthosite plutons (e.g., Nukasusutok, Carey, and Sandy Islands, Fig. 2). All the dykes 
in the area (except the late unmetamorphosed E-W trending Nain dykes (Gower et al. 1990) crosscut the migmatitic and schlieric gneisses at a high angle but are subsequently themselves crosscut by the NPS. Suggesting that the apparent concordance of the gneissic country rocks with the anorthosites is not due to reorientation during pluton emplacement but rather to the pluton contacts paralleling the regional trend of gneissosity. In detail, the gneissic layering and local trends are truncated by the intrusive contacts. Overall map patterns indicate that the trends were probably established prior to the emplacement of the NPS (Fig. 2).

Unstrained contact-metamorphic replacement of regional garnet by cordierite and hypersthene, and sillimanite by corderite and spinel, has been recorded (Berg 1977; Speer 1982). Fieldwork in the area showed that both pseudomorphous assemblages retain the shape of the primary phase without any flattening or stretching of the original morphology, implying a low degree of strain associated with the thermal overprint in the contact aureoles (Ryan 1991,1992; Royse and Ryan 1995) and suggesting that the intrusion of the NPS did not result in large scale deformation within the country rocks.

$\mathrm{U}-\mathrm{Pb}$ ages from zircon and monazite within rock units on islands east of Nain (Connelly and Ryan 1996) indicate emplacement of the schlieric granitoid gneisses at ca. $2578 \pm 3$ Ma $(\mathrm{U} / \mathrm{Pb})$, emplacement of some mafic dykes at $2559 \pm 10 \mathrm{Ma}$, and mylonitisation, shearing, and granulite-facies metamorphism at ca. $2578 \pm 3$ to $2549 \pm 3 \mathrm{Ma}$. This $30 \mathrm{Ma}$ period of magmatism and tectonism resulted in the formation of the Nain Province (Connelly and Ryan 1996) i.e., the amalgamation of the Hopedale and Saglek blocks. A 
similar structural history with comparable ages of intrusion and metamorphism is found in the Okak area (Van Kranendonk 1992; Schiøtte et al. 1990) in off-shore northern Labrador (Wasteneys et al. 1992) and in the region west of Hopedale (Loveridge et al. 1987), which is indicative of a regional event corroborating the amalgamation model (Wasteneys et al. 1992). This event (D2) was probably synchronous with the emplacement of the schlieric granitoid gneiss (Royse et al. 1994; Royse and Ryan 1995) (see Table 1). The region was largely quiescent until the intrusion of the Nain Plutonic Suite (NPS) between 1350 and 1290 Ma (Ryan and Emslie 1994; Morse 1971-1983; Ryan 1990), with the majority of the anorthosite plutons being emplaced over a $17 \mathrm{Ma}$ period (Hamilton et al. 1993; Hamilton 1993). The location of the NPS plutons along the boundary between the Nain and Churchill provinces and also in the zone of amalgamation between the Saglek and Hopedale blocks is significant, perhaps suggesting that crustal weaknesses may have controlled the emplacement of the Nain anorthosites.

Dykes. All the country rock gneisses described above are cross-cut by an assemblage of mafic dykes of various ages, emplaced under both ductile and brittle conditions. All the dykes have been recrystallised at amphibolite or granulite facies, and are described in detail by Ryan (1995). The occurrence of two pyroxenes and hornblende within some of the dykes is indicative of the transitional stage from amphibolite to pyroxene-hornfels facies, and is attributed to the contact-metamorphic effect of the NPS.

Certain dykes dated at $1316 \pm 1.5$ to $1327 \pm 1.5 \mathrm{Ma}$ (Cadman et al. 1999) falls within the emplacement dates of the NPS and are considered to be genetically related. 
Shear zones. Ductile shear zones developed under metamorphic conditions that vary from granulite- to greenschist-facies. Individual shear zones transect the gneisses and the dykes throughout the study area.

The geometric relationships between the dated basic dykes with ages between 1327 and $1316 \mathrm{Ma}$ (Cadman et al. 1999) and associated shear zones indicate that these dykes are coeval with movements on the shear zones. Cadman et al. (1995) interpret a change in viscosity contrast between dykes and gneisses from the earlier to the later dykes as indicating intrusion during a period when the host-rock temperatures were declining, which suggests that the shear zones were reactivated at the time of NPS emplacement when the country rocks were hot, and continued to be active as the area cooled down.

The shear zones display evidence for at least two periods of movement. The first is probably related to the D2 Archaean event. The second, which generally post-dates peak metamorphic conditions of Mesoproterozoic age, which is found to have taken place around the time of emplacement of the NPS (Table 1). Certain smaller shear zones, e.g., on Moskie Island, record both stages of movement.

\section{Margins of the Nain Anorthosite}

The NPS exhibits two radically different types of contact with its country rocks, a feature emphasised by Ryan (1991, 1992). Some anorthosites, especially those found inland in the western and central parts of the NPS, exhibit strongly foliated margins parallel to the 
outline of the pluton-gneiss contact: e.g., the Mount Lister intrusion (Ryan 1991, 1993), the Bird Lake massif(Morse 1981), and the Pearly Gates intrusion (Ryan 1993). Other plutons show no signs of deformation, exhibit slightly oblique to sharply discordant intrusive contacts against their country-rock hosts, and have an abundance of locally derived host-rock inclusions. These undeformed plutons exhibit contacts that can further be divided into two types, namely (i) contacts in which easily identified igneous rocks directly abut gneisses, and (ii) contacts where the igneous-textured plutonic rocks are separated from country rocks by mafic granulites whose origin is not easily deduced, but which are intruded by the adjacent igneous rocks. The latter contact type is well developed along part of the outer zone of the Jonathon intrusion on Jonathon Island, Carey Island and Dog Island (Ryan 1991; Royse and Ryan 1995) and along the eastern side of the Paul Island intrusion on Paul Island (Berg et al. 1994). We will focus on the Mount Lister intrusion and the Jonathon intrusion as examples of the deformed and undeformed types respectively.

Internal characteristics of the Nain anorthosite have not been as well documented, as have been the coastal exposures. However, texturally the intrusions are heterogeneous at outcrop scale with reports of plagioclase crystals varying from mm's to tens of $\mathrm{cm}$ across (largest recorded at $70 \mathrm{~cm}$ ) and the plutons, overall appearance changes from massive to diffusely layered, to well layered, to foliated (Ryan 1997, 1998).

The Mount Lister intrusion. The eastern side of this large intrusion has been examined in shoreline outcrops along the west side of Webb Bay, and to the south of the bay (Fig. 1). 
There, it is composed of coarse-grained to very coarse-grained, highly foliated, gneissic leuconorite and intensely deformed anorthosite at its margin, and less deformed to massive anorthositic and noritic rocks in the interior. The gneissose character of the margin is enhanced by primary layering between anorthositic and leuconoritic components (Fig. 3) and by the presence of deformed anorthositic xenoliths that are attenuated along strike. The characteristic rock of the deformed margin is one in which white recrystallised plagioclase surrounds augen-like relics of dark-grey primary igneous plagioclase, and coarse orthopyroxene is broken down to lozenge-shaped elongate granular aggregates retaining the original coarse-grained pyroxene in the core (Ryan 1992; Royse 1997). Gneissose olivine-clinopyroxene monzonite, dated at ca.1347 Ma (Connelly and Ryan 1993) forms a discontinuous sheath, up to 100 m wide, separating the anorthosite and norite from Archaean granulite-facies gneisses (Ryan 1993). The age of this monzonite is one of the oldest documented from the NPS, and if it represents a close approximation of the age of crystallisation of the adjacent anorthositic rocks, then this pluton and all similar foliated rocks of the NPS may be the earliest intrusions to have been emplaced. The deformed margin of the Mount Lister intrusion at Webb Bay is at least $100 \mathrm{~m}$ wide, and the fabric within it dips steeply to the east. Foliation planes are noteworthy in having a lineation that plunges shallowly to moderately $\left(18^{\circ}-34^{\circ}\right)$ to the southeast, which indicates a normal oblique-slip to strike-slip movement sense. Shear sense indicators give a dextral sense of movement. This lineation geometry poses problems for any model ascribing foliation formation to simple vertical diapiric emplacement. 
The Jonathon Intrusion. The western margin of the Jonathon Island intrusion (Berg and Briegel 1983), $35 \mathrm{~km}$ northeast of Nain, represents the second type of pluton-gneiss contact. This olivine-bearing leuconoritic to noritic intrusion is bordered by a discontinuous zone of layered, granular, mesocratic, and melanocratic basic rocks, dominated by olivine gabbro and olivine gabbro-norite, that are well displayed in icescoured outcrops along the shorelines of Jonathon, Carey, and Dog islands (Fig. 1). These basic zones are up to $500 \mathrm{~m}$ wide and separate the anorthositic pluton from the Archaean quartzofeldspathic gneiss. These rocks are a greenish brown to black weathering and characterised by the presence of elongate "stringers" and podiform pyroxene aggregates. Layering composition can vary greatly across the border zone from pale green pyroxenite, dark brown lherzolite to leucogabbro/anorthosite. Unlike the regional basic gneisses, the layered rocks abutting the Jonathon Island intrusion lack significant hydrous minerals and contain poikilitic olivine (Fig. 4). Brecciated fragments can be found within the marginal zone, particularly on Carey Island (Fig. 4). The layering in the marginal zone is locally chaotic and displays slump folding, and slides, and is crosscut by olivine-bearing mafic dykes (Ryan 1991; Royse and Ryan 1995; Royse 1997). Large orthopyroxene pods and pegmatitic xenoliths of leuconorite (which on the northern shore of Dog Island are up to a metre in width) crosscut the layering within the marginal series. These are interpreted as the products of bottom or wall accumulation within the magma chamber during its early evolutionary stages.

The marginal layered rocks of the Jonathon intrusion lack the intense and pervasive tectonic foliation that characterises the margin of the Mount Lister intrusion and appear 
to have many features in common with the outer border zone of the Kiglapait intrusion (e.g., they are mafic, granular, layered and contain mafic xenoliths). The margin of the Michikamau intrusion in western Labrador is also reported to have similar layered rocks along its margin (Ryan, 1991). The marginal rocks of both these intrusions have been subject to considerable debate (Morse 1969; Wheeler 1942, 1960; Berg 1977).

\section{Rheological constraints}

Ascent rates from megacrysts. Large orthopyroxene megacrysts, varying in size from a few centimetres up to a metre in width, are found within anorthosite massifs (Emslie 1975; Morse 1975; Berg et al. 1994). It should be noted that not all giant orthopyroxene crystals found within the NPS are megacrysts. Some are an integral part of the pegmatitic leuconoritic rocks (Ryan 1991; Royse and Ryan 1995). Geobarometry carried out by Emslie (1975) suggested that the megacrysts crystallised at $\sim 15-20$ kbar and $1120{ }^{\circ} \mathrm{C}$, approximating to 40-60 km depth. Wiebe (1986) carried out further experimental work and suggested that these megacrysts crystallised at a maximum pressure of $11 \mathrm{kbar}$. Since Berg (1977) inferred that the pluton crystallised at mid crustal depths at around $6 \mathrm{~km}$, the anorthositic crystal mush must have ascended some $34 \mathrm{~km}$.

Dymek and Gromet (1984) and Owens and Dymek (1995) have suggested that similar pyroxene megacrysts found within the Labrieville massif and Saint Urban Anorthosite, Québec, are products of in-situ crystallisation. However, in the Nain complex, the occurrence of unexsolved high-Al megacrysts in alkali-basalt dykes (Weibe 1986) with identical chemical features to the plagioclase-bearing megacrysts (Emslie 1975), and 
because pyroxene megacrysts are the most primitive material in several massifs (including the NPS), having the most primitive initial isotopic ratios of $\mathrm{Sr}$ and $\mathrm{Nd}$ (Ashwal 1993); It is considered that the orthopyroxene megacrysts found in the NPS have characteristics that support a deep-seated origin.

These megacrysts are used here to estimate the minimum ascent rates of the anorthositic crystal mush by balancing frictional and buoyancy forces acting on the orthopyroxene megacrysts while settling at its terminal velocity (Spera 1980).

The rheological condition of an anorthositic crystal mush must be considered if we are to obtain an estimate of its ascent rate. The rheology is dependent on a complicated mix of several factors: strain rate, composition, temperature, pressure, and crystal, bubble and water content (Webb and Dingwell 1990; Weinberg and Podladchikov 1995). Knowledge of the crystal state is also critical in ascertaining its rheological behaviour (Fernandez and Gasquet 1994; Kerr and Lister 1991). Most magmas ascend through the crust at subliquidus temperatures (Sparks et al. 1977) and therefore will contain crystals. The rheological behaviour of magma changes significantly during progressive crystallisation (Kerr and Lister 1991; Fernandez and Gasquet 1994; Petford and Koenders 1998). As such, a model relying on Newtonian behaviour (i.e., where a fluid's viscosity is independent of the rate of shear or velocity gradient) would give spurious results (Miller and Paterson 1999). 
Assuming non-Newtonian behaviour of the magma, the terminal velocity $\left[\mathrm{V}_{\mathrm{n}}\right]$ of orthopyroxene megacrysts can be calculated using the equation below (Spera 1980):

$$
\mathrm{V}_{\mathrm{n}}=0.344\left(\Delta \rho \mathrm{g} / \rho_{\mathrm{l}}\right)^{5 / 7}\left(\rho_{\mathrm{n}} / \mu\right)^{3 / 7}\left(\mathrm{R}_{\mathrm{n}}-\left(3 \mathrm{k} \sigma_{0} / 4 \Delta \rho \mathrm{g}\right)\right)^{8 / 7}
$$

where $\rho_{\mathrm{n}}=$ density of the megacryst, $\mathrm{k}=$ a dimensionless constant equal to about $5, \mathrm{R}_{\mathrm{n}}=$ the radius of the megacryst, $\rho_{l}=$ the density of the magma or liquid that surrounds the megacryst, $g=$ acceleration due to gravity, $\Delta \rho=$ the change in density, and $\mu=$ viscosity of the magma. $\sigma_{0}=$ the yield strength which can be approximated to the volume fraction of crystals within the surrounding liquid by the equation:

$$
\sigma_{\mathrm{o}}=\mathrm{K}_{1} \Phi^{3}
$$

where $\mathrm{K}_{1}=$ an empirically derived constant having the dimensions of stress $=3 \times 10^{4} \mathrm{~Pa}$ and $\Phi=$ volume fraction of crystals. $\sigma_{\mathrm{o}}$ is also dependent on the size of the solid fraction (Jeffrey and Acrivos 1976; Fernandez and Gasquet 1994).

In a Bingham fluid (i.e., a fluid which exhibits a yield strength which must be exceeded before flow can start) the megacrysts of orthopyroxene will have to reach a minimum radius before they can sink through the magma. Timoshenko and Goodier (1970) and later Sparks et al. (1977) suggested that the minimum radius can be calculated by relating the yield strength of the liquid (as in equation 2) to the density ratio between the liquid and the crystal. Thus:

$$
\mathrm{r}^{*}=3 \mathrm{~K} \sigma_{\mathrm{o}} / 4 \Delta \rho \mathrm{g}
$$


where $\mathrm{r}^{*}=$ the critical radius below which the crystal will not sink, $\mathrm{K}=\mathrm{a}$ dimensionless constant equal to about $5, \mathrm{~g}=$ acceleration due to gravity, and $\Delta \rho=$ the change in density.

Orthopyroxene megacrysts within the NPS have been observed over a metre in length (Emslie 1975; Morse 1975; Ashwal 1993), but on average they range between 10 , and 50 $\mathrm{cm}$ in radius. Orthopyroxene megacrysts can be assumed to have a density of approximately $3.4 \mathrm{~g} / \mathrm{cm}^{3}$ (Deer et al. 1985). The composition of the parental magma to massif-type anorthosites has long been a topic of debate (Morse 1982; Emslie et al. 1994) It has been suggested that the presence of Al-Fe rich gabbros found in close proximity to anorthosite plutons, e.g., the NPS (Royse et al. 1999), and the Laramie, Harp Lake, Adirondacks, and Kiglapait intrusions (Olson and Morse 1990), are important in the quest to find a parental magma to massif-type anorthosites. These liquids could not produce the required amounts of plagioclase directly (Fram and Longhi 1992; Emslie et al. 1994), and therefore they must be mechanically enriched. One method of doing this is by a polybaric crystallisation history (Longhi and Ashwal 1985; Emslie et al. 1994). An Al-Fe rich magma at high pressures, which was already fractionating olivine, orthopyroxene, and spinel at the base of the crust, could end up with a magma containing a high proportion of plagioclase due to the appearance of a peritectic point at $15 \mathrm{kbar}$. If this magma is emplaced into mid-crustal regions, it would crystallise plagioclase alone on the liquidus.

Therefore, for simplification, the magma will be assumed to be predominantly plagioclase-rich, and hence to have a density of $2.5-2.7 \mathrm{~g} / \mathrm{cm}^{3}$, dependent on its 
crystallinity (Bottinga and Weill 1970; Sparks and Huppert 1984; Marsh 1995). A value of $2.6 \mathrm{~g} / \mathrm{cm}^{3}$ was taken as the most appropriate estimate for the anorthositic crystal mush, and $3.4 \mathrm{~g} / \mathrm{cm}^{3}$ for the orthopyroxene megacrysts, giving a density contrast of $0.8 \mathrm{~g} / \mathrm{cm}^{3}$.

The viscosity of the magma is taken from the experimental results of Cranmer and Uhlmann (1981) and Hummel and Arndt (1985). Since the average An value is $\mathrm{An}_{55}$ (Morse 1978), and the ambient temperature was $\sim 1120^{\circ} \mathrm{C}$ (Emslie 1975), a viscosity of $1 \times 10^{6}$ Pa.s is appropriate. However, this does not take into account the crystal content (i.e., the proportion of solid material in the magma) of the magma, nor changes of viscosity with depth (Cserepes 1993). It is possible to account for the solid-fraction by calculating the solid-fraction-dependent effective viscosity (Marsh 1981; Vigneresse et al. 1996); if the solid fraction is taken as between $5-30 \%$, then viscosity can be calculated as between $1 \times 10^{6}$ and $5 \times 10^{6}$ Pa.s using the equation:

$$
\mu_{\mathrm{e}}=\mu(1-1.67 \mathrm{~F})^{-2.5}
$$

where $\mu_{\mathrm{e}}=$ the effective viscosity, $\mu=$ viscosity of the liquid, and $\mathrm{F}=$ the solid fraction. Table 2 lists several terminal velocities (settling rates) of orthopyroxene megacrysts at differing crystallinities. Crystallinities greater than $50 \%$ were not considered, as at that point the magma changes from a mushy magma to a body which is mostly solid (Marsh 1988). In granite magmas, when crystallinities reach 30 to $35 \%$, enclaves stop sinking, and other gravity processes become less efficient (Lejeune and Richet 1995).

From equations $1-4$, terminal velocities within the crystallinity range $0-50 \%$ were found to vary between $8.2 \mathrm{~cm} / \mathrm{s}$ and $5.0 \mathrm{~cm} / \mathrm{s}$. These velocities give minimum ascent rates for the 
magma, since, if the megacrysts are not to remain neutrally buoyant, the magma must travel faster than these terminal velocities. Whichever mechanism is invoked for the emplacement of anorthosite, it must allow for an ascent rate faster than these terminal velocities.

Diapiric ascent. If an anorthositic crystal mush ascended through the crust diapirically then the rate of ascent can be approximated by Stokes' equation for the velocity of a solid sphere moving through a Newtonian fluid. The equation can be extended to Newtonian, and inviscid spheres by accounting for the effects of the viscosity and, therefore the drag of the magmatic body itself (Batchelor 1967, eq. 4.9.30):

$$
\mathrm{V}=1 / 3\left(\Delta \rho \mathrm{g} \mathrm{d}^{2} / \mu_{\mathrm{c}}\right)\left(\mu_{\mathrm{c}}+\mu_{\mathrm{m}} / \mu_{\mathrm{c}}+3 / 2 \mu_{\mathrm{m}}\right)
$$

where $\mathrm{V}=$ ascent rate, $\mathrm{d}=$ thickness of the drag zone (approximately equal to the radius of the body), $g=$ acceleration due to gravity, $\Delta \rho=$ the change in density, $\mu_{\mathrm{m}}=$ viscosity of the plutonic body, and $\mu_{\mathrm{c}}=$ viscosity of the country rock.

Morse (1983) noted that there are many different sizes of pluton within the NPS and that the exact dimensions of many of the individual plutons are unknown (Ryan et al. 1997, 1998). However, Emslie (1980) suggested a maximum diameter of $10 \mathrm{~km}$ for the Harp Lake complex, and the Susie Brook slab is known to be $\sim 10 \times 20 \mathrm{~km}$ in area. It would seem reasonable, therefore, to assume that the anorthositic plutons within the NPS have a maximum diameter of $10 \mathrm{~km}$. Country rock viscosity is assumed to be similar to that of typical lower crust, around $10^{22}$ Pa.s (Cathles 1975; Clemens 1998), and the viscosity of 
the magma is as equation 1 . The density of the country rock is taken as $2.74 \mathrm{~g} / \mathrm{cm}^{3}$ (Royse 1997), and that of the anorthositic crystal mush as $2.6 \mathrm{~g} / \mathrm{cm}^{3}$.

Using the above data, the ascent rate works out at approximately $3 \times 10^{-9} \mathrm{~cm} / \mathrm{s}$. This is extremely slow, and it would take approximately $31 \mathrm{Ma}$ for the magma to rise some 30 $\mathrm{km}$. Succeeding bodies ascend faster than the initial diapir because drag is reduced. For example, if the diapir were half the initial size it would ascend through the crust 25 times faster (Marsh 1982; Weinberg 1996), reducing the ascent rate to $7.5 \times 10^{-8} \mathrm{~cm} / \mathrm{s}$. However, this is still slower by 8 orders of magnitude than the terminal velocities of megacrysts calculated using equation 4 .

If thermal constraints are taken into consideration (Spera 1980; Whitehead and Helfrich 1991; Bejan 1993; Marsh 1995; Yoshinobu et al. 1998), the argument against diapiric ascent of these bodies is strengthened. As Marsh (1982) suggested, if a diapir is to retain a reasonable speed of ascent, its wall rocks must be heated to at least its solidus, which for granitic lower crust is in the region of $\sim 650^{\circ} \mathrm{C}$ (Yoshinobu et al. 1998). This will effectively reduce the wall rock viscosity, and consequently the drag exerted on the body. This requires the pluton to convect vigorously in order to maintain heat at its margins (Marsh 1982). From the above considerations, it would appear that, for a rise of $30 \mathrm{~km}$ (estimated from orthopyroxene megacrysts within the anorthosites), likely ascent rates are such that it would take far too long a time to reach current levels in the crust. Gravitational ascent is therefore only viable if the pluton rises short distances, and has a significant density contrast. 
The above calculation assumes that the surrounding country rock behaves according to Newtonian principles. However, Kirby (1983), and Wilks and Carter (1990) showed, in laboratory experiments using natural strain rates, pressures, and temperatures, that crustal rocks can behave as power-law fluids. This modification would not make a significant difference to the calculated ascent rate, but it would cause significant characteristic deformational effects in the country rocks (Rubins 1993; Paterson et al. 1996; Miller and Paterson 1999). The surrounding crust will have strain aureole widths significantly smaller than those produced if the crustal rock behaved in a Newtonian manner. The strain aureole width is controlled by several factors, e.g., viscous flow, stoping, and assimilation of wall rocks, as well as doming of the roof. Diapirs rising within Bingham or non-Newtonian fluids will have aureole widths that decrease with increasing viscosity, such that the flow concentrates around the diapir (Weinberg 1994), and the margins would thus be expected to deform at a faster rate than the core (Weinberg and Podladchikov 1995), resulting in non-Newtonian diapirs being surrounded by a strongly sheared margin.

Conduit ascent. An alternative mechanism to diapirism is for ascent to take place via fractures or conduits to mid-crustal depths. If the anorthositic crystal mush rose through the crust by fracture propagation, it is possible to approximate this mathematically by using simple pipe flow equations to calculate the flow velocity [V] (Delaney and Pollard 1981):

$$
\mathrm{V}=\mathrm{g} \Delta \Delta \mathrm{w}^{2} / 12 \mu_{\mathrm{m}}
$$


where $\mathrm{w}=$ width of the dyke or fracture , and $\mu_{\mathrm{m}}=$ viscosity of the magma. The buoyancy contrast ( $g \Delta \Delta$ ) between the magma, and the country rock is the driving force in both equations 5 and 6 . In equation 6 , the buoyancy contrast is related inversely to the viscosity of the magma $\left(\mu_{\mathrm{m}}\right)$, but in equation 5 it is linked to the viscosity of the country rock $\left(\mu_{\mathrm{c}}\right)$. Therefore, the more viscous the magma, the slower the rate of ascent by conduit propagation. To estimate the ascent rate, it is first necessary to compute the critical dyke width. Several authors have calculated this for granitic magmas: Petford et al. (1993) suggest that for granite magmas with viscosities between $10^{4}$ Pa.s and $10^{8} \mathrm{~Pa} . \mathrm{s}$, rising 30-20 km through the crust, critical dyke widths are between 2 and 20m; Corry (1988) estimates felsic dyke widths of 1-4m; and Clemens and Mawer (1992) calculate a critical dyke width of $2.7 \mathrm{~m}$ for a magma with a viscosity of $10^{5} \mathrm{~Pa} . \mathrm{s}$ through a $20 \mathrm{~km}$ long fracture. Noritic dyke widths in the study area vary from $<0.1 \mathrm{~m}$ to $18 \mathrm{~m}$ (Cadman and Ryan 1994). Estimates for melt densities, and viscosities were used as above.

The minimum rates of ascent for an anorthositic crystal mush, into the crust calculated on the above basis, are for dyke widths of $2 \mathrm{~m}, 0.09 \mathrm{~cm} / \mathrm{s}$, and for dyke widths of $18 \mathrm{~m}$, $7.56 \mathrm{~cm} / \mathrm{s}$. This is comparable to the ascent rates of $0.1 \mathrm{~cm} / \mathrm{s}$ calculated for fracture propagation of granites by Clemens and Mawer (1992), and for the Cordillera Blanca batholith by Petford et al. (1993), and is of the same order of magnitude as the ascent rate estimated from the settling velocity of orthopyroxene megacrysts. As the ascent rate estimated here is the minimum rate possible, it is conceivable that the width of the dyke or fracture may have been larger than $20 \mathrm{~m}$. 
Petford and Koenders (1998) have shown that for a crystal mush moving through a dyke, simple Newtonian flow will not apply. It is possible to account for the effects of suspended crystals by using the work of Mctigue and Jenkins (1992), and Nott and Brady (1994). However, it should be noted that deviation from simple Newtonian flow is unlikely to be significant until the magma has stopped ascending, and emplacement (pluton filling) begins (Petford and Koenders 1998).

\section{Discussion}

The above arguments indicate that diapirism would be too slow to be a viable mechanism of ascent for an anorthositic crystal mush. If the orthopyroxene megacrysts observed in the NPS (Emslie 1975; Morse 1975; Wiebe 1986) are to reach their present level in the crust after crystallising at depths of 40-60 km (Emslie 1975; Wiebe 1986), the magma must ascend at a faster rate than the settling velocity of the megacrysts. Moreover, if diapiric ascent had occurred, evidence for vertical displacement should be recorded both in the country rocks, and within the deformation aureole itself (Marsh 1982; Mahon et al. 1988; Bateman 1984). Such effects have not been observed anywhere in the NPS.

The dyke propagation mechanism, on the other hand, is consistent with models that require rapid emplacement of anorthosite into the crust (Morse 1982; Fran and Longhi 1992; Berg 1980). For instance, Morse (1982) suggested that a basaltic liquid hypersaturated in plagioclase, if rapidly emplaced, could produce massif-type anorthosites. The anorthosite plutons were intruded over a period of $17 \mathrm{Ma}$ (Hamilton et al. 1993; Hamilton 1993). The rate at which magma was emplaced can thus be estimated 
to be in the order of $0.01 \mathrm{~km}^{3}$ per year (areal extent, and depth can be approximated from Bouger anomaly maps). This rate is slower, but comparable to, those recorded for the build-up of Phanerozoic rift zones $\left(3-5 \mathrm{~km}^{3}\right.$ per year) and of continental crust $\left(0.4 \mathrm{~km}^{3}\right.$ per year) (White and McKenzie 1989). Supporting the hypothesis that NPS anorthosites were emplaced rapidly, dyke propagation is the most likely mechanism for the emplacement of the NPS.

There are many examples in the literature where the emplacement style, and the location of plutons are considered to be controlled by major faults, and shear zones (Castro 1987; Brun 1990; Schmidt et al. 1990; Hutton and Reavy 1992; Petford and Atherton 1992). The great tonalite sill of southeastern Alaska and British Columbia (Ingram and Hutton 1994) is considered to have exploited an active shear zone, as is the Strontian granite, which is thought to have been emplaced dextrally within a releasing bend of the Great Glen fault (Hutton 1988).

It is proposed that the fundamental control on the emplacement, migration, and ascent of an anortositic crystal mush within the Nain area is the Abloviak shear zone, which represents a plane of weakness within the Precambrian crust that would be mechanically favourable to dyke propagation, since rocks within the shear zone's medial plane would have been deformed repeatedly, and therefore be weak (Hutton 1992). It is likely that the magma intruding into an established shear zone will locally increase displacement rates in that area. Such instability, once created, would draw more magma into the zone until the pluton had crystallised, and the viscosity contrast within the zone had disappeared. 
Another zone of structural weakness, which could easily be exploited by incoming magma, is the zone of amalgamation between the northern Saglek, and southern Hopedale blocks, as pointed out by Connelly and Ryan (1996).

The margins of the Mount Lister intrusion display a dextral sense of movement. Many major N-S shear zones, particularly in the Nuksasusutok Island area, were reactivated in a dextral sense at the time of NPS emplacement, which is confirmatory evidence of a genetic link between shear-zone activity and anorthosite emplacement. The plutons, thus fed by the dykes, would initially assume a sill-like form, but continued supply of magma would cause the plutons to expand, and assume their present form.

The strike-slip movement observed in both the Lister massif, and the Pearly Gates intrusion indicates that there is no change in the crustal level at which the plutons were emplaced. This is confirmed by the fact that there is no difference in the contact aureoles surrounding those plutons with foliated margins, and those without. This suggests that the change in the appearance of the plutons from east to west across the NPS is likely to be related solely to changes in the ductility of the country rock into which they are intruded.

Similar conclusions were reached by Davies (1982) to account for differences in the emplacement features observed in certain Pan African granites. Those granitic plutons that were emplaced into the Ajjaj shear zone are elongate, and concordant with strike. Conversely, those granites emplaced outside the shear zone into brittle wall rocks are rectilinear bell-jar shaped cauldrons. A related observation was made by Corriveau and 
Leblanc (1995), who suggested that magma emplacement styles within the Grenville province of Québec were controlled by host rock rheology. The form, and shape of the Nain anorthosites are considered, therefore, to reflect the mechanism of ascent, the tectonic conditions during emplacement, and the physical properties of the crust into which they were emplaced, rather than any change in crustal level.

\section{Conclusions}

Calculation of settling velocities of orthopyroxene megacrysts found within many of the plutons of the NPS place a minimum rate of ascent for an anorthositic crystal mush, which is many orders of magnitude faster than that calculated for diapiric emplacement. The monomineralic nature of anorthosite, and its high solidus temperature would mean that, as with basalts, anorthosites would have to be emplaced relatively rapidly into the crust in order to reach mid-crustal levels in a geologically realistic period of time. It is deduced that only dyke propagation would provide a sufficiently rapid ascent rate.

It is suggested that the Abloviak shear zone, and the zone of juxtaposition between the Saglek, and Hopedale blocks of the Nain province acted as structurally weak pathways for the passage of anorthosite, which was dilationally emplaced along steep pre-existing shear zones, and solidified completely at mid-crustal levels. Continued emplacement of the anorthositic crystal-mush gave rise to high-strain zones in the earlier formed marginal material. The inter-relationship between cavities tectonically created by movement along the shear zone and by internal magma buoyancy forces resulted in the complex geometries observed in the plutons of the NPS. Differences in emplacement style across 
the NPS from west to east can be accounted for by changes in the ductility contrast between the anorthosite, and the country rocks, those intrusions which were emplaced into thermally softened rocks of the Abloviak shear zone having foliated margins and those emplaced in the east into cold Archaean crust having undeformed margins.

\section{Acknowledgements}

This study forms part of a PhD thesis by K.R. Royse funded by the UK Natural Environment Research Council. Logistic support for the fieldwork was provided by the geological Survey branch of the Department of Mines and Energy, Newfoundland. K.R. Royse would also like to thank her field assistants Jonathan Royse and Edward Brown and also A.B. Ryan for his invaluable support and advice. Louise Corriveau, Michael Higgins, and Frank Spera are thanked for their constructive and helpful reviews.

\section{References}

Ashwal, L.D. 1993. Anorthosites. Springer, Berlin.

Batchelor, G.K. 1967. An Introduction to Fluid Dynamics. Cambridge University Press, England.

Bateman, R. 1984. On the role of diapirism in the segregation, ascent and the final emplacement of granitoid magmas. Tectonophysics, 110: 221-231.

Bejan, A. 1993. Heat transfer. John Wiley and Sons, Inc., New York.

Berg, J.H. 1977. Regional geobarometry in the contact aureoles of the anorthositic Nain complex, Labrador. Journal of Petrology, 18: 399-430.

Berg, J.H. 1979. Physical constraints and tectonic setting of the Nain complex (abstract). Geological Association of Canada, Abstracts with Program, 4: 39. 
Berg, J.H. 1980. Snowflake troctolite in the Hettasch Intrusion, Labrador: Evidence for magma mixing and supercooling in a plutonic environment. Contributions to Mineralogy and Petrology, 72: 339-351.

Berg, J.H; and Briegel, J.S. 1983. Geology of the Jonathon Island intrusion and associated rocks. The Nain Anorthosite Project, Labrador: field reports. Department of Geology, University of Massachusetts. Amherst, Massachusetts. Contributions 40: 43-50.

Berg, J.H., Emslie, R.F., Hamilton, M.A., Morse, S.A., Ryan, A.B., and Wiebe, R.A. 1994. Anorthositic, granitoid and related rocks of the Nain Plutonic suite. Field excursion to the Nain area. International geological correlation programme IGCP projects \#290 and \#315.

Bottinga, Y., and Weill, D.F. 1970. Densities of liquid silicate systems calculated from partial molar volumes of oxide components. American Journal of Science, 269:169182.

Brun, J.P., Gapais, D., Cogne, J.P., Ledru, P., and Vigneresse, J.L. 1990. The Flamanville granite (northwest France): an unequivocal example of a syntectonically expanding pluton. Geological Journal, 25: 271-286.

Cadman, A.C., and Ryan B. 1994. An investigation of some metamorphosed dykes of the Nain area, Labrador, part 2. Geochemistry of the Akkuneq Dykes of the Dog Island region. Current Research, Newfoundland Department of Mines and Energy, Geological Survey Branch, Report 4-1: 333-345.

Cadman, A.C., Ryan, B., Royse, K.R., and Noble, S.R. 1995. An investigation of some metamorphosed dykes of the Nain area: part 3-geochemistry and structural 
relationships in the Nukasusutok Island area. Current Research, Newfoundland Department of Natural Resources, Geological Survey Report 95-1: 1-14.

Cadman, A.C., Noble, S.R., Ryan, B., Tarney, J. Royse, K.R., and Park, R.G. 1999. U-Pb geochronological evidence for Syn-shear intrusion of mafic dykes. Canadian Journal of Earth Sciences, 36: 339-348

Cathles, L.M. III. 1975. The viscosity of the Earth's mantle. Princeton University Press, Princeton, New Jersey.

Castro, A. 1987. A review on granitoid emplacement and related structures. Geologische Rundschau, 76: 101-124.

Clemens, J.D. 1998. Observations on the origins and ascent mechanisms of granitic magmas. Journal of the Geological Society of London, 155: 843-851.

Clemens, J.D., and Mawer, C.K. 1992. Granitic magma transport by fracture propagation. Tectonophysics, 204: 339-360.

Connelly, J.N., and Ryan, B. 1993. U-Pb constraints on the thermotectonic history of the Nain area. In Eastern Canadian Onshore- Offshore Transect (ECSOOT), Report of Transect meeting (December 4-5, 1992). Edited by R.J. Wardle, and J. Hall, University of British Columbia, Lithoprobe Secretariat, Report 32: 137-144. Connelly, J.N., and Ryan, B. 1996. Late Archaean evolution of the Nain province, Nain Labrador: imprint of a collision. Canadian Journal of Earth Sciences, 33: 13251342.

Corret, C. E. 1988. Laccoliths: Mechanisms of emplacement and growth. Geological Association of America Special Publication 220. 
Corriveau, L., and Leblanc, D. 1995. Sequential nesting of magmas in marble, southwestern Grenville Province, Quebec: from fracture propagation to diapirism. Tectonophysics, 246: 183-200.

Cranmer, D., and Uhlmann, D.R. 1981. Viscosities in the system albite-anorthite. Journal of Geophysical Research, 86: 7951-7956.

Cruden, A.R. 1990. Flow and fabric development during the diapiric rise of magma. Journal of Geology, 98: 681-698.

Cserepes, L. 1993. Effect of depth-dependent viscosity on the pattern of mantle convection. Geophysical Research Letters, 20: 2091-2094.

Davies, F.B. 1982. Pan-African granite intrusion in response to tectonic volume changes in a ductile shear zone from northern Saudi Arabia. Journal of Geology, 90: 467483.

Deer, W.A., Howie, R.A., and Zussman, J. 1985. An introduction to rock-forming minerals. Longman, London.

Delaney, P. T. 1982. Solidification of basaltic magma during flow in a dyke. American Journal of Science, 282: 856-885.

Delaney, P.T., and Pollard, D.D. 1981. Deformation of host rocks and flow of magma during growth of minette dykes and breccia bearing intrusions near Ship rock, New Mexico. US. Geological survey. Washington, D.C.

D’Lemos, R.S., Brown, M., and Strachan, R.A. 1992. Granite magma generation, ascent and emplacement within a transpressional orogen. Journal of the Geological Society, London, 149: 487-490. 
Dymek, R.F., and Gromet, L.P. 1984. Nature and origin of orthopyroxene megacrysts from the St-Urbain anorthosite massif, Quebec. Canadian Mineralogist, 22: 297326.

Emslie, R.F. 1975. Pyroxene megacrysts from anorthositic rocks: new clues to the sources and evolution of the parental magmas. Canadian Mineralogist, 13: 138-145.

Emslie, R.F. 1980. Geology and petrology of the Harp Lake complex, central Labrador: an example of Elsonian magmatism. Geological Survey of Canada Bulletin, 293.

Emslie, R.F., and Hunt, P.A. 1990. Ages and petrogenetic significance of igneouscharnockite suites associated with massif anorthosites, Grenville province. Journal of Petrology, 98: 213-232.

Emslie, R.F., Morse, S.A, and Wheeler, E.P. 1972. Igneous rocks of central Labrador with emphasis on anorthositic and related intrusions. Guide book, field excursion A54, 24th International Geological Congress.

Fernandez, A.N., and Gasquet, D.R. 1994. Relative rheological evolution of chemically contrasted coeval magmas: example of Tichka plutonic complex (Morocco). Contributions to Mineralogy and Petrology, 116: 316-326.

Fram, M.S., and Longhi, J. 1992. Phase equilibria of dykes associated with Proterozoic anorthosite complexes. American Mineralogist, 77: 605-616.

Grant, J.A., and Frost, B.R. 1990. Contact metamorphism and partial melting of pelitic rocks in the aureole of the Laramie Anorthosite complex, Morton Pass, Wyoming. American Journal of Science, 290: 425-475.

Gower, C.F., Rivers, T., and Brewer, T.S. 1990. Middle Proterozoic mafic magmatism in Labrador, Eastern Canada. In mid-Proterozoic Laurentia-Baltic. Edited by C.F. 
Gower, T. Rivers, and A.B. Ryan. Geological Association of Canada Special Paper, 38: $485-506$.

Hamilton, M.A., Emslie, R.F., and Roddick J.C. 1993. Detailed emplacement chronology of basic magmas of the Mid-Proterozoic Nain Plutonic Suite, Labrador: insights from U-Pb systematics in zircon and baddeleyite. Eight International Conference on Cosmochronology and Isotope Geology. United States Geological Survey, Circular 1107.

Hamilton, M.A. 1993. Contamination of massif anorthosite and Precambrian crustal evolution in central Labrador: a combined trace element and $\mathrm{Sr}, \mathrm{Nd}$ and $\mathrm{Pb}$ isotopic study. Ph.D. Thesis, University of Massachusetts, Boston.

Hummel, W., and Arndt, J. 1985. Variation of viscosity with temperature and composition in the plagioclase system. Contributions to Mineralogy and Petrology, 90: 83-92.

Hutton, D.H.W. 1988. Igneous emplacement in a shear-zone termination biotite granite at Strontian, Scotland. Geological Society of America Bulletin, 100: 1392-1399.

Hutton, D.H.W. 1992. Granite sheeted complexes: Evidence for the dyking ascent mechanism, in Second Hutton Symposium on the origin of granites and related rocks, September 1991, Proceedings: Royal Society of Edinburgh Transactions: Earth Sciences, 83: 377-382.

Hutton, D.W., and Reavey, R.J. 1992. Strike-slip tectonics and granite petrogenesis. Tectonics, 11: 960-967.

Ingram, G.M., and Hutton, D.H.W. 1994. The great Tonalite Sill: emplacement into a contractional shear zone and implications for late Cretaceous to early Eocene 
tectonics in southeastern Alaska and British Columbia. Geological Society of America Bulletin, 106: 715-728.

Jeffrey, D.J., and Acrivos, A. 1976. The rheological properties of suspensions of rigid particles. Journal of the American Institute of Chemical Engineering, 22: 417-435.

Kerr, R.C., and Lister, J.R. 1991. The effects of shape on crystal settling and rheology of magmas. Journal of Geology, 99: 457-467.

Kirby, S.H.1983. Rheology of the lithosphere. Reviews in Geophysics and Space Physics, 21: 1458-1487.

Leake, B.E., 1978. Granite emplacement: the granites of Ireland and their origin. In Crustal evolution of Northwest Britain and Adjacent Regions. Edited by D.R. Bowes and B. E. Leake. Geological Journal Special Issue, 10: 221-248.

Lejeune, A.M., and Richet, P. 1995. Rheology of crystal-bearing silicate melts: an experimental study at high viscosities. Journal of Geophysical Research, 100: 4215-4229.

Longhi, J., and Ashwal, L.D. 1985. Two stage models for Lunar and terrestrial anorthosites: petrogenesis without a magma ocean. Proceedings of the Fifteenth Lunar and Planetary Science Conference, Part 2 Journal of Geophysical Research 90: supplement, C571-C584.

Loverage,W.D., Ermanovics, I.F., and Sullivan, R.W. 1987. U-Pb ages on zircon from the Maggio gneisses, the Kanairiktok Plutonic Suite and the Island Harbour Plutonic Suit, coast of Labrador, Newfoundland. Radiogenic Age and Isotope Studies: report 1. Geological Survey of Canada, pp. 59-65 
Mahon, K.L., Harrison, T.M., and Drew, D.A. 1988. Ascent of a granitoid diapir in a temperature varying medium. Journal of Geophysical Research, 93: 1174-1188.

Marsh, B. D. 1981. On the crystallinity, probability of occurrence and rheology of lava and magma. Contributions to Mineralogy and Petrology, 78: 85-98.

Marsh, B. D. 1982. On the mechanics of igneous diapirism, stoping, and zone melting. American Journal of Science, 282: 808-855.

Marsh, B. D. 1995. Solidification fronts and magmatic evolution. Mineralogical Magazine, 60:5-40

Martignole, J., and Schrijver, K. 1970. Tectonic setting and evolution of the Morin anorthosite, Grenville province, Quebec. Bulletin of the Geological Society of Finland, 42: 165-209.

Mctigue, D.F. and Jenkins, J.T. 1992. Channel flow of a concentrated suspension. In Advances in micromechanics of granular materials. Edited by H.H. Shen. Elsevier Science Publishers BV, Amsterdam, 381-390.

Mengel, F. and Rivers, T. 1989. Thermotectonic evolution of Proterozoic and reworked Archaean terranes along the Nain-Churchill boundary in Saglek area, northern Labrador. In Evolution of metamorphic belts. Edited by J.S. Daly. (ed.) Geological Society, London Special Publication, 43: 319-324.

Miller, R.B., and Paterson, S.R. 1999. In defence of magmatic diapirs. Journal of Structural Geology, 21:1161-1173.

Morse, S.A. 1969. The Kiglapait Layered Intrusion, Labrador. Geological society of America, Memoir 112. 
Morse, S.A. 1975. Plagioclase lamellae in hypersthene, Tikkoatokhakh Bay, Labrador. Earth and Planetary Science Letters, 26: 331-336.

Morse, S.A. 1978. Plagioclase composition and anorthosite classification. The Nain Anorthosite Project, Labrador: field reports. Department of Geology, University of Massachusetts. Amherst, Massachusetts. Contribution, 26: 51-57.

Morse, S.A. 1981. Emplacement History of the Nain Complex. The Nain Anorthosite Project, Labrador: field reports. Department of Geology, University of Massachusetts. Amherst, Massachusetts. Contribution, 38: 9-15.

Morse, S.A. 1982. A partisan review of Proterozoic anorthosites. American Mineralogist, 67: $1087-1100$.

Morse, S.A. 1983. Emplacement history of the Nain complex . The Nain Anorthosite Project, Labrador: field report. University of Massachusetts, Department of Geology and Geography. Contribution, 40: 223-234.

Nott, P.R., and Brady, J.F. 1994. Pressure driven flow of suspensions: Simulation and theory. Journal of Fluid Mechanics, 275: 157-199.

Olson, K.E. and Morse, S.A. 1990. Regional Al-Fe mafic magmas associated with anorthosite-bearing terranes. Nature, 344: 760-762.

Owens, B.E., and Dymek, R.F. 1995. Significance of pyroxene megacrysts for massif anorthosite petrogenesis: constraints from the Labrieville, Québec, pluton. American Mineralogist, 80: 144-161.

Paterson, S.R., Fowler Jr. T.K., and Miller, R.B. 1996. Pluton emplacement in arcs: a crustal-scale exchange process. Transactions of the Royal Society of Edinburgh, Earth Sciences, 87: 115-124. 
Petford, N., and Atherton, M.P. 1992. Granitoid emplacement and deformation along a major crustal lineament: the Cordillera Blanca, Peru. Tectonophysics, 205: 171185.

Petford, N., and Koenders, M.A. 1998. Granular flow model and viscous fluctuations in low Bagnold number granitic magmas. Journal of the Geological Society, 155: 873881.

Petford, N., Kerr, R.C. and Lister, J.R. 1993. Dyke transport model for transport of granitoid magmas. Geology. 21: 845-848.

Petford, N., Lister, J.R. and Kerr, R.C. 1994. The ascent of felsic magmas in dykes. Lithos, 32:161-168.

Pitcher, W.S. 1979. The nature, ascent and emplacement of granitic magmas. Journal of the Geological Society, London, 136: 627-662.

Ramsey, J.G. 1989. Emplacement kinematics of a granite diapir: the Chindamora batholith, Zimbabwe. Journal of Structural Geology, 11:191-209.

Royse, K.R. 1997. Origin and emplacement of the Nain anorthosite, Labrador: a structural and geochemical study. Ph.D. Thesis, University of Keele, Staffordshire.

Royse, K.R., and Ryan, B. 1995. Structural evolution and emplacement of the Nain Plutonic Suite in the Dog Island area. In Current Research (1995). Newfoundland Department of Natural Resources, Geological Survey Branch, Report 95-1, pp. 3745.

Royse, K.R., Park, R.G., and Cadman, A.C. 1994. The geology of an area around Nukasusutok Island, Southeast of Nain (including Paul Island and Sandy Island). In 
Current Research (1994). Newfoundland Department of Mines and Energy, Geological Survey Branch, Report 94-1, pp. 387-398.

Royse, K.R., Noble, S.R., Tarney, J., and Cadman, A. 1999. Country rock contamination of marginal mafic granulites bordering the Nain Plutonic Suite: implications for mobilisation of Sr during high-grade contact metamorphism. Canadian Journal of Earth Sciences, 36: 985-997.

Rubin, A.M. 1993. Dykes vs. diapirs in viscoelastic rock. Earth and Planetary Science Letters, 119: 641-659.

Ryan, B. 1990. Preliminary geological map of the Nain Plutonic Suite and surrounding rocks (Nain - Nutak, NTS 14 SW). Newfoundland Department of Mines and Energy, Geological Survey Branch, Map 90-44, Scale 1:500 000.

Ryan, B. 1991. New perspectives on the Nain Plutonic Suite and its country rocks. In Current research (1991). Newfoundland Department of Mines and Energy, Geological Survey Branch, Report 91-1, pp. 231-255.

Ryan, B. 1992. Nain area geology: observations on selected islands, and the area south of Nain bay. In Current research (1992). Newfoundland Department of Mines and Energy, Geological Survey Branch, Report 92-1, pp. 381-398.

Ryan, B. 1993. Further results of mapping gneissic and plutonic rocks of the Nain area, Labrador. In Current research (1993). Newfoundland Department of Mines and Energy. Geological Survey Branch, Report 93-1, pp.61-75.

Ryan, B. 1995. Morphological features of multigenerational basic dykes near Nain, Labrador: clues to the original emplacement mechanisms and subsequent deformation. Precambrian Research, 75: 91-118. 
Ryan, A.B., and Emslie, R.F. 1994. Pre-Elsonian mafic magmatism in the Nain igneous complex, Labrador: the Bridges layered intrusion-comment. Precambrian Research, 68: $179-181$.

Ryan, B., Hynes, A., and Ermanovics, I. 1997. Geology of the Nain plutonic suite and its country-rock envelope, Alliger lake area (NTS 14E/1), Labrador. In Current research (1997). Newfoundland Department of Mines and Energy. Geological Survey Branch, Report 97-1 pp. 29-47.

Ryan, B., Phillips, E., Shwetz, J., and Machado, G. 1998. A tale of more than ten plutons (geology between Okak bay and Staghorn lake, Labrador (parts of NTS maps 14E/2,7,8). In Current research (1998). Newfoundland Department of Mines and Energy, Geological Survey Branch, Report 98-1 pp.143-171.

Schiøtte, L., Noble, S.R., and Bridgwater, D. 1990. U-Pb mineral ages from northern Labrador: possible evidence for interlayering of early and mid Archaean tectonic slices. Geoscience Canada, 17: 227-231.

Schmeling, H., Cruden,A.R., and Marquart, G. 1988. Finite deformation in and around a fluid sphere moving through a viscous medium: implications for diapiric ascent. Tectonophysics, 149:17-34.

Schmidt, D., Smedes, H. W., and O'Neill, J.M. 1990. Syncompressional emplacement of Boulder and Tobacco Root batholiths (Montana-USA) by pull- apart along old fault zones. Geological Journal, 25: 305-318.

Scott, D.J. 1998. An overview of the U-Pb geochronology of the Paleoproterozoic Torngat orogen, Northeast of Canada. Precambrian Research, 91: 91-107. 
Simmons, G. 1964. Gravity survey and geological interpretation, Northern New York. Geological Society of America Bulletin, 75: 81-98.

Sparks, S.J. and Huppert, H.E. 1984. Density changes during fractional crystallisation of basaltic magmas: fluid dynamic implications. Contributions to Mineralogy and Petrology, 85: 300-309.

Sparks, R.S.J., Pinkerton, H. and Macdonald, R. 1977. The transport of xenoliths in magmas. Earth and Planetary Science Letters, 35: 234-238.

Speer, F. 1982. Metamorphism of pelitic rocks of the Snyder group in the contact aureole of the Kiglapait layered intrusion, Labrador: effects of buffering partial pressures of water. Canadian Journal of Earth Sciences, 19: 1888-1909.

Spera, F.J. 1980. Aspects of magma transport. In Physics of magmatic processes. Edited by Hargraves, R.B. Princeton University Press, Princeton, N.J.

Spera, F.J., Borgia, A., Strimple, J., and Feigenson, M. 1988. Rheology of melts and magmatic suspensions, 1 Design and calibration of rhyolitic magma. Journal of Geophysical Research, 93: 10273-10294.

Thomas, M.D. 1990. Deep structure of middle Proterozoic anorthosite intrusions in the eastern Canadian shield: insights from gravity modelling. In Mid-Proterozoic Laurentia-Baltica. Edited by C.F. Gower, T. Rivers and B. Ryan. Geological Association of Canada Special Paper, 38: 353-373.

Valley, J.W., and O’Neil, J.R. 1982. Oxygen isotope evidence for shallow emplacement of the Adirondack anorthosite. Nature, 300: 497-500.

Van Kranendonk M.J. 1992. Geological evolution of the Archaean Nain Province and Early Proterozoic Torngat orogen as seen along a transect in the North River - 
Nutak Map area, northern Labrador, Canada. Unpublished Ph.D thesis, Queen's University, Kingston, Canada.

Van Kranendonk M.J., and Wardle R.J. 1997. Crustal-scale flexural slip folding during late tectonic amplification of an orogenic boundary perturbation on the Paleoproterozoic Torngat orogen, northeastern Canada. Canadian Journal of Earth Sciences, 34:1545-1565.

Vigneresse, J.L., Barbey, P., and Cuney, M. 1996. Rheological transitions during partial melting and crystallization with application to felsic magma segregation and transfer. Journal of Petrology, 37: 1579-1600.

Wasteneys, H., Wardle, R.J., and Krogh, T.E. 1992. Exploration of tectonic boundaries across the Labrador shelf: U-Pb geochronology of well samples. In Eastern Canadian Onshore-Offshore Transect (ECSOOT), Report of Transect meeting (December 4-5, 1992). Edited by R.J. Wardle and J.Hall. University of British Columbia, Lithoprobe Secretariat, Report 32: 145-173.

Webb, S.L., and Dingwell, D.B. 1990. Non-newtonian rheology of igneous melts at high stresses and strain rates: experimental results for rhyolite, andesite, basalt and nephelinite. Journal of Geophysical Research, 95:15695-15701.

Wheeler, E.P. 1942. Anorthosite and related rocks about Nain Labrador coast. Journal of Geology, 50: 611-642.

Wheeler, E.P. 1960. Anorthosite-adamellite complex of Nain, Labrador. Bulletin of the Geological Society of America, 71: 1755-1762.

Wheeler, J. 1987. The determination of true shear senses from the deflection of passive markers in shear zones. Journal of the Geological Society, London, 144: 73-77. 
White, R., and Mckenzie, D. 1989. Magmatism at the rift zones: the generation of volcanic continental margins and flood basalts. Journal of Geophysical Research, 94: 7685-7729.

Whitehead, J.A., and Helfrich, K.R. 1991. Instability of flow with temperaturedependent viscosity: a model of magma dynamics. Journal of Geophysical Research, 96: 4145-4155.

Wiebe, R.A. 1986. Lower crustal cumulate nodules in Proterozoic dykes of the Nain complex, evidence for the origin of Proterozoic anorthosites (Labrador, Canada). Journal of Petrology, 27: 1253-1275.

Wiebe, R.A. 1990. Evidence for unusually feldspathic liquids in the Nain complex, Labrador. American Mineralogist, 75: 1-12.

Wienberg, R.F., and Podladchikov, Y. 1994. Diapiric ascent of magmas through power law crust and mantle. Journal of Geophysical Research, 99: B5, 9543-9559.

Wienberg, R.F., and Podladchikov, Y. 1995. The rise of solid-state diapirs. Journal of Structural Geology, 17:1183-1195.

Wilks, K. R., and Carter, N.L. 1990. Rheology of some continental lower crustal rocks. Tectonophysics, 182: 57-77.

Williams, G.L., Fyffe, L.R., Wardle, R.J., Colman-Sadd, S.P., Boehner, R.C. and Watt, J.A. (Editors) 1985. Lexicon of Canadian Stratigraphy. Volume 11: Atlantic Region. Canadian Society of Petroleum Geologists.

Yoshinobu, A.S., Okaya, D.A., and Paterson, S.R. 1998. Modeling the thermal evolution of fault-controlled magma emplacement models. Journal of Structural Geology, 20: 1205-1218. 
Table 1: Geochronology of the Nain area gneisses; data compiled from Connelly and Ryan (1996), Hamilton (1993), Karlson et al. (1993) and Cadman et al. (1999)

U-Pb Age (Ma)

$1276 \pm 23$

$1350-1290$

(1312-1309

Age of plutons in study area)

Emplacement of the

Nain Plutonic Suite

Nain LP and HP dykes

\section{Event}

\section{Deformation and Metamorphism.}


Table 1: U-Pb Geochronology of the Nain area gneisses; data compiled from Connelly and Ryan (1996), Hamilton (1993), Karlson et al. (1993) and Cadman et al. (1999)

\begin{tabular}{lll}
\hline U-Pb Age (Ma) & Event & Deformation and Metamorphism.
\end{tabular}

$1276 \pm 23$

Nain LP and HP dykes

1350-1290

Emplacement of the

Thermal resetting of $\mathrm{U}-\mathrm{Pb}$

(1312-1309

Nain Plutonic Suite

ages $1311 \pm 7-1305 \pm 5 \mathrm{Ma}$

Age of plutons in study area)

associated with pyroxene

hornfels facies contact

metamorphism; remobilisation

of shear zones

$1327 \pm 2.5-1316 \pm 1.5$

Second phase of

dyke emplacement

$1667 \pm 75$

Emplacement of the Bridges

intrusion 
$2060 \pm 14-2020 \pm 17$

$2578 \pm 3-2550 \pm 3$

$2578 \pm 3$

$3600 \pm 21-2670 \pm 3$
Pink granite

emplacement

Mylonitisation (D2) of

migmatitic gneisses and

granulite facies metamorphic

event

First phase of dyke intrusion

Lit par lit injection of

Enclaves of older material

granitoid gneisses

reset thermally; granitoid

gneiss emplaced at amphibolite

facies
Intrusion of early migmatitic Early foliation preserved in

gneiss

boundinaged mafic dykes;

migmatisation followed by

D1 event and granulite

facies metamorphism 
Table 2: Settling rates $V_{n}$ of orthopyroxene megacrysts within an anorthositic crystal mush (from equation 1 ), where $\mathrm{R}_{\mathrm{n}}=$ radius of the megacryst $\mathrm{r}^{*}=$ the critical radius (see equation 3$), \sigma_{\mathrm{o}}=$ yield strength values derived from equation 2 and $\Phi=$ the volume fraction of crystals.

\begin{tabular}{lllll}
\hline $\mathrm{R}_{\mathrm{n}}(\mathrm{cm})$ & $\mathrm{r}^{*}(\mathrm{~cm})$ & $\sigma_{\mathrm{o}}\left(\right.$ dyne $\left.^{-2}\right)$ & $\Phi$ & $\mathrm{V}_{\mathrm{n}}(\mathrm{cm} / \mathrm{s})$ \\
\hline 50 & 0 & 0 & 0 & 8.19 \\
50 & 0.14 & 30 & 0.1 & 8.17 \\
50 & 2.19 & 468.7 & 0.25 & 7.79 \\
50 & 17.57 & 3750 & 0.5 & 4.99 \\
\hline
\end{tabular}


Table 2: Settling rates Un of orthopyroxene megacrysts within an anorthositic crystal mush (from equation 1 ), where $\mathrm{R}_{\mathrm{n}}=$ radius of the megacryst $\mathrm{r}^{*}=$ the critical radius (see equation 3 ), $\sigma_{0}=$ yield strength values derived from equation 2 and $\Phi=$ the volume fraction of crystals.

\begin{tabular}{lllll}
\hline $\mathrm{R}_{\mathrm{n}}(\mathrm{cm})$ & $\mathrm{r}^{*}(\mathrm{~cm})$ & $\sigma_{\mathrm{o}}\left(\right.$ dyne $\left.\mathrm{cm}^{-2}\right)$ & $\Phi$ & $\mathrm{V}_{\mathrm{n}}(\mathrm{cm} / \mathrm{s})$ \\
\hline 50 & 0 & 0 & 0 & 8.19 \\
50 & 0.14 & 30 & 0.1 & 8.17 \\
50 & 2.19 & 468.7 & 0.25 & 7.79 \\
50 & 17.57 & 3750 & 0.5 & 4.99 \\
\hline
\end{tabular}


Figure Captions

Fig. 1: Map of field study area. Letters refer to specific units or islands: $\mathrm{H}=$ Hettash Intrusion, $\mathrm{PM}=$ Portmanvers Run anorthosite, $\mathrm{T}=$ Tigalak intrusion, NILI= Newark Island intrusion, $\mathrm{L}=$ Mount Lister Massif, $\mathrm{J}=$ Jonathan intrusion, $\mathrm{BLM}=$ Bird Lake Massif, $\mathrm{A}=$ Akpaume intrusion, $\mathrm{B}=\mathrm{Barth}$ Island intrusion, $\mathrm{PG}=$ Pearly Gates intrusion, $\mathrm{R}=$ Reid Brook intrusion, $\mathrm{TI}=$ Tunungayaluk intrusion, $\mathrm{C}=$ Carey Island, $\mathrm{K}=$ Kikkertavak intrusion, $\mathrm{S}=$ Sandy Island and $\mathrm{N}=$ Nukasusutok Island. The inset outlines the major tectonic divisions in Labrador (see text for details).

Fig. 2: Diagram depicting foliation trends within the study area; see text for detail.

Stereonets show: A contoured equal area plot of the migmatised gneiss, B the distribution of F2 axial planes (0) and fold axes (+), line represents the position of the regional fold axis, $\mathrm{C}$, poles to layering in the granitoid gneiss, showing position of the regional $\mathrm{F} 2$ axis, and $\mathrm{D}$, stereographic projection of the mineral lineation in the granitiod gneiss and minor fold axis $(+)$ of F2 folds in the Dog island area (northern map section). Dyke orientations are also depicted on rose diagrams. The change in orientation between the northern and southern map is due to the presence of large-scale shear zones in the south.

Fig. 3: Photograph from the margin of the Lister Massif in the Webb Bay area, displaying strongly foliated margin containing podiformed and recrystallised plagioclase surrounding original primary plagioclase crystals. Also note the attenuation of orthopyroxene which accentuates the gneissic character of the rocks.

Fig. 4: Photograph of the western margin of the Jonathon Island intrusion taken on Carey Island. Margin contains layered norite to gabbro-norite rocks. Brecciated noritic 
fragments are surrounded by leuconorite. In the centre of the photograph note the xenoliths of mafic gneiss, which contain podiformed hornblende. 